\title{
SYMBOLIKA PEJZAŻU (WEWNĘTRZNEGO) W FILMACH CARLOSA REYGADASA
}

Katarzyna Citko

Instytut Studiów Kulturowych, UwB

Institute of Cultural Studies, University of Bialystok

k.citko@uwb.edu.pl

ORCID: 0000-0002-7246-6921

Carlos Reygadas jest jednym z bardziej znanych i cenionych współczesnych reżyserów meksykańskich. Jego filmy mają wydźwięk autobiograficzny, jest to kino osobiste, rozpoznawalne dzięki autorskiemu stylowi filmowego opowiadania oraz poruszanej tematyce i wymowie symbolicznej, niejednokrotnie zaskakujące widzów niestereotypowymi rozwiązaniami. Reygadas, filmowiec-samouk, poeta kina i wizjoner, realizuje dzieła, w których bogata metaforyka i skrajne emocje tworzą niezwykle intensywny przekaz. Reżyser w swoich dziełach poszukuje czegoś więcej niż realistycznego odzwierciedlenia świata, ale też nie interesują go fantastyczne czy baśniowe opowieści; w jego filmowej twórczości dochodzi do głosu przekonanie autora, że widzowie nie chodzą do kina, by uciec od życia, tylko po to, aby w pełni doświadczać jego wielowątkowości i tajemnicy. Reygadas deklaruje:

For me, each film is an act of life, of existence. I never think of myself as making a career out of this. Everything just reflects a moment of my existence, of my being. So I don't know what I'm doing next and I don't care much. Whatever I do, there will have to be a deep, powerful, internal need and will come out when it has to come out ${ }^{1}$.

1 „Dla mnie każdy film jest aktem życia. Nie traktuję tego jako sposobu na zrobienie kariery. To wszystko jest po prostu odzwierciedleniem mojego bycia, momentu, w którym się znajduję. Więc nie wiem, co będę robił za chwilę i nie interesuje mnie to. Cokolwiek to będzie, będzie wynikać z mojej głębokiej wewnętrznej potrzeby i pojawi się, kiedy nadejdzie odpowiedni moment. Jeśli ma to być udane, to będzie" [tłum. K.C.] - cytat z portalu IMDb. Zob. Carlos Reygadas, http://www.imdb.com/name/ nm1196161/ [dostęp 23.09.2018]. 
Przyjętą w artykule metodą badawczą jest analityczny opis wybranych pejzaży, pełniących istotną rolę w filmach Carlosa Reygadasa oraz interpretacja symboliki w nich zawartej, zgodnie z przyjętą perspektywą fenomenologiczno-hermeneutyczną. Zastosowanie narzędzia badawczego, jakim jest interpretacyjna analiza fenomenologiczna, umożliwia zarówno opis obrazów (pejzaży) występujących w filmach Reygadasa, jak i ukazanie ich symbolicznych znaczeń. Przedmiotem zainteresowania dokonywanych analiz jest sytuacja życiowa bohaterów filmowych, uwikłanych w splot różnorodnych wydarzeń i zmuszonych do podejmowania trudnych wyborów. Działają oni w konkretnej przestrzeni pejzaży filmowych, których symboliczne konotacje dookreślają ich emocje, wybory i postawy, stanowiąc zarazem egzemplifikację światopoglądu i istoty artystycznej kreacji samego autora filmowych dzieł. Obraz świata ukazany na ekranie, wypływający z przeżyć, uczuć i światopoglądu reżysera, zaprasza widzów do kontemplacji, emocjonalnego przeżycia i osobistego odczytywania sensów. Jest on równocześnie wynikiem oryginalnej koncepcji sztuki filmowej Reygadasa, mającej swoje korzenie w twórczości wielkich reżyserów kina światowego, takich jak: Andriej Tarkowski, Carl Theodor Dreyer czy Robert Bresson.

Charakterystyczną cechą filmów Reygadasa jest autorskie traktowanie warstwy temporalnej i wizualnej dzieł. Specyfika czasu i przestrzeni, traktowanych jako tworzywo, generuje strukturę opowiadania filmowego, określa jego formę i stanowi, jak podkreśla Małgorzata Steciak, esencję sztuki w rozumieniu meksykańskiego reżysera ${ }^{2}$.

Pejzaże pojawiające się w filmach Reygadasa ewokują różnorodne znaczenia związane $z$ opowiadaną na ekranie fabułą, a równocześnie z głębszą warstwą obrazowania o charakterze symbolicznym. Odwołują się one do symboli kosmicznych i religijnych, powszechnie znanych w tradycji kulturowej Meksyku oraz całego świata, a zarazem do wyobraźni i emocji samego reżysera - mają więc charakter zarówno uniwersalny, jak i jednostkowy.

Już w pierwszym fabularnym filmie Reygadasa, Japón (2002), pojawia się pejzaż nacechowany znaczeniem. Bohater, którego imienia nie znamy, ucieka ze stolicy w góry, aby tam na pustkowiu, w samotności popełnić samobójstwo. Motywy jego decyzji nie zostaną widzom ujawnione; sugestia

2 M. Steciak, Kino współczesne. Carlos Reygadas: Film jest naczyniem, „Ekrany” 2019, nr 3-4(49-50), s. 80. 
raczej niż wyjaśnienie przywołuje kryzys twórczy mężczyzny, który jest malarzem. Bohater zatrzymuje się w domku starszej, ubogiej wdowy Ascen. Surowy, ale piękny pejzaż gór oraz prostota i pokora staruszki powodują przemianę bohatera: mężczyzna rezygnuje $z$ odebrania sobie życia, a nawet występuje w obronie swojej gospodyni przed brutalnym siostrzeńcem, który roszcząc sobie prawo do części majątku, chce zburzyć jej siedlisko. Kluczowa dla przemiany duchowej bohatera scena ukazuje moment, w którym rezygnuje on $z$ aktu samobójczego. Mężczyzna wspina się po zboczu na krawędź wysokiego kanionu, wędrując w strugach ulewnego deszczu który przywołuje czytelną symbolikę oczyszczenia, odrodzenia i nowego życia - aby na szczycie przeżyć znaczącą transformację.

Podobny motyw wędrówki bohatera na szczyt odnajdziemy w filmie Bitwa w niebie (2005). Obraz wspinaczki ukazuje protagonistów obu dzieł w chwili ich duchowego i moralnego kryzysu. W obydwu filmach wizerunek wstępujących ku górze mężczyzn zestawiony został z sugestywnymi obrazami chmur, mgły i padającego deszczu. Symbolika tych przedstawień w obu dziełach jest tożsama: bohaterowie, wędrując wzwyż, przekraczają sferę codzienności i wchodzą w przestrzeń i czas sacrum. Związane jest to z kryzysem egzystencjalnym, który przeżywają, oraz z nurtującym ich dogłębnie pragnieniem osiągnięcia transcendencji, rozumianej przez nich jako możliwość wyjścia z tego kryzysu.

Reżyser odwołuje się w scenach z obydwu filmów do symboliki judeochrześcijańskiej, czerpiąc z tradycji kulturowej katolickiego Meksyku. Chmury, obłoki i mgła są zapisanym w Biblii wyrazem obecności Boga, który przychodzi na spotkanie z człowiekiem. Obłok symbolizuje tajemniczość i niedostępność Boga, Jego transcendencję. Motyw ten odnajdziemy zarówno w Starym, jak i w Nowym Testamencie. W Księdze Wyjścia słup obłoku towarzyszy Izraelitom podczas wyjścia z niewoli egipskiej. Zawarcie przymierza Boga z ludem na górze Synaj również dokonuje się pod osłoną chmur: „Pan rzekł do Mojżesza: „Oto Ja przyjdę do ciebie w gęstym obłoku, aby lud słyszał, gdy będę rozmawiał z tobą, i uwierzył tobie na zawsze«. A Mojżesz oznajmił Panu słowa ludu" [Wj 19,9] ${ }^{3}$. Potem zaś poszedł na

3 Pismo Święte Starego i Nowego Testamentu. Biblia Tysiąclecia, wyd. V, Poznań 2013, s. 86. 
spotkanie z Panem, który osłonił górę gęstą mgłą ${ }^{4}$ Mgła, jak wyjaśnia Juan Eduardo Cirlot $^{5}$, symbolizuje to, co nieokreślone, jeszcze bez wyraźnych granic, moment przemiany, strefę mroku pomiędzy każdym z elementów czy każdą z faz zjawiska, oznaczać może również przejście między sferą profanum a sacrum.

Obłok unosił się nad Namiotem Spotkania [Wj 40,34-38] oraz nad Świątynią Jerozolimską po wniesieniu do niej Arki Przymierza [1Krl 8,10-12]. W Nowym Testamencie obłok świetlany osłonił Jezusa i apostołów na górze Tabor podczas Przemienienia Pańskiego [Mt 17,5]. Również w czasie wniebowstąpienia Chrystusa „obłok zabrał Go im [apostołom - przyp. K.C.] sprzed oczu" [Dz 1,9 $]^{6}$, zaś w dniu Sądu Ostatecznego wszystkie narody „ujrzą Syna Człowieczego, przychodzącego na obłokach niebieskich z wielką mocą i chwałą" [Mt 24,30] $]^{7}$ W przytoczonych fragmentach widać wyraźnie, że symbolika chmur ukazuje w Biblii zbliżenie, moment przyjścia Boga do człowieka na spotkanie $\mathrm{z}$ nim.

Bohater filmu Japón wdrapuje się na górę i zatrzymuje nad stromą ścianą kanionu, na krawędzi przepaści. Wyciąga z kieszeni rewolwer, ale nie strzela do siebie, tylko unosi go i celuje prosto w niebo nad swoją głową. Kamera podążając za tym ruchem, panoramuje w górę, ukazując szary, nieprzenikniony pułap chmur i nieruchomieje w długim, jednolitym punkcie spojrzenia na niebiosa. Zdają się one milczeć; jeżeli gdzieś tam za chmurami jest Bóg, to znacząco odległy. A jednak towarzyszący scenie ulewny deszcz przynosi czytelną symbolikę oczyszczenia i łaski. W kolejnym ujęciu widzimy, że bohater chowa broń i odchodzi. Przy leżącym na trawie ścierwie konia pada na ziemię i leży zwrócony twarzą do nieba, a obrazowi temu towarzyszy z offu aria Erbarme dich, Mein Gott z Pasji według św. Mateusza Johanna Sebastiana Bacha. Słowa pieśni przywołują miłosierdzie Boże; kamera z lotu ptaka ukazuje leżącego bohatera, kołuje nad nim i nad zwłokami konia, po czym ponownie w przedłużającym się nieruchomym spojrzeniu ukazuje szare, ale rozświetlone jednolitym blaskiem niebo. W kolejnych ujęciach

4 Hebrajskie słowo ed oznacza „opar” i tłumaczone jest w Biblii Tysiąclecia zazwyczaj jako: „obłok”.

5 J.E. Cirlot, Stownik symboli, tłum. I. Kania, Kraków 2006, s. 109.

${ }^{6}$ Pismo Święte..., op. cit., s. 1266.

7 Ibidem, s. 1172. 
bohater schodzi w dół kanionu; wraca ku zabudowaniom wioski, a jednocześnie rozpoczyna swoją wewnętrzną wędrówkę ku życiu, porzucając myśli o samobójstwie.

W filmie Bitwa w niebie protagonista Marcos wspina się na szczyt góry podczas rodzinnej wycieczki za miasto. Dziecko przyjaciółki, które porwał dla okupu, właśnie przypadkowo zmarło. Marcos musi podjąć decyzję, jak ma się zachować w zaistniałych okolicznościach. W dodatku opowiedział o wszystkim córce swojego szefa i teraz obawia się, że dziewczyna wyda go w ręce policji. Sytuację komplikuje fakt, że jest w niej beznadziejnie i bez wzajemności zakochany.

Marcos odłącza się od swojej rodziny i zaczyna wspinać się na szczyt wzgórza. Ta wędrówka ma wymiar symboliczny; widzowie nie otrzymują żadnego racjonalnego wyjaśnienia, dlaczego bohater wdrapuje się na wierzchołek, przedzierając się przez zarośla i gęstniejącą mgłę, która spowija pejzaż szczelnym całunem. Mgła pojawia się niespodziewanie i można odnieść wrażenie, że to ona prowokuje bohatera do podjęcia wędrówki na szczyt górującego nad okolicą stromego wzniesienia.

W tradycji biblijnej, jak już zostało wspomniane, mgłę, obłoki czy słupy chmur zsyła na ziemię Bóg, wtedy gdy przychodzi na spotkanie z człowiekiem. Wchodzący na górę Marcos staje więc „w oku Boga”, a osłaniające go opary symbolizują pozorność przemian skrywających odwieczną, niezmienną istotę najwyższej Prawdy.

Funkcjonująca w wielu kulturach świata symbolika góry związana jest z wyrażeniem jej aspektu sakralnego. Podkreśla to Cirlot, pisząc:

Jak w przypadku krzyża lub drzewa kosmicznego, umiejscowienie tej góry-symbolu zaznacza „centrum” świata. Znają ten głęboki symbol bodaj wszystkie tradycje [...]. Mistyczny sens wierzchołka wynika również z faktu, że jest on punktem złączenia nieba i ziemi, centrum, przez jakie przechodzi oś świata ${ }^{8}$.

Podobnie znaczenie symbolu góry wyjaśnia Matilde Battistini:

Góra to miejsce, w którym ujawnia się sacrum (hierofania) lub bóstwo (teofania) [...]. W prawie wszystkich teogoniach góra jest miejscem największej

8 J.E. Cirlot, op. cit., s. 141-142. 
koncentracji boskiej obecności. [...] Święta góra wznosi się w centrum świata i - podobnie jak krzyż, schody, drabina czy drzewo - stanowi jego oś i korzenie; symbolizuje także cechy duchowe człowieka9 .

Marcos staje na szczycie góry i, podobnie jak protagonista Japón, spogląda w przepaść. Na górze nie ma mgły; długie, statyczne ujęcie eksponuje bohatera obok umieszczonego na skale dużego wotywnego krzyża. Panoramująca kamera przenosi spojrzenie widzów z postaci bohatera na błękitne niebo nad jego głową; ponownie mamy tu do czynienia z punktem widzenia kamery skierowanej prostopadle w górę, tak jak miało to miejsce w Japón. Słońce i wiejący na szczycie wiatr symbolizują obecność Boga; hebrajskie słowo ruah oznacza zarówno wiatr, tchnienie, jak i ducha, utożsamianego w Biblii z Duchem Świętym. Pismo Święte w wielu fragmentach opisuje spotkanie Boga z wybranym przez Niego człowiekiem, które dokonuje się w powiewie wiatru; przywołać tu można chociażby scenę z Księgi Królewskiej, w której prorok Eliasz staje twarzą w twarz z Jahwe na górze Horeb [1Krl 19,11-13]. Marcos, podobnie jak biblijny Eliasz, wchodzi w sferę sacrum i spotyka Boga. Świadczyć może o tym gest zakrycia dłońmi oczu przez bohatera. W ten sposób, zasłaniając sobie twarz, reagowali pobożni Żydzi na przyjście Boga czy chociażby Jego anioła.

Do Marcosa stojącego na szczycie góry przemawia więc Bóg, podobnie jak przemówił do bohatera Japón - ale Marcos nie słyszy Bożego wezwania; przegapia skierowaną do niego epifanię i - w ostateczności - przegrywa batalię o swoje życie. W obydwu filmach Reygadasa towarzyszący wspinaczce protagonistów górski pejzaż ma charakter symboliczny, ewokujący sferę sacrum, przywołujący transcendencję pożądaną przez bohaterów jako możliwość wyjścia z kryzysu, ale zarazem nieosiągalną.

Stan wewnętrznego rozdarcia cechujący bohaterów obydwu swoich filmów Reygadas wyraża za pomocą obrazów o charakterze kontemplacyjnym, pięknych samych w sobie - ich forma artystyczna łączy się zarazem z funkcjami semantycznymi. I tak w Japón surowy krajobraz nagich gór, skłaniający do kontemplacji ich urody, jest zrazem ilustracją samotności i wyobcowania bohatera szukającego życzliwej osoby, która pomogłaby mu popełnić samobójstwo. Z kolei w Bitwie w niebie tłem dla opowiedzianej

9 M. Battistini, Symbole i alegorie, tłum. K. Dyjas-Fezzi, Warszawa 2005, s. 241. 
historii jest ruchliwe niczym mrowisko miasto, pełne obojętnych wobec siebie ludzi; staje się ono egzemplifikacją stanu psychicznego Marcosa, na próżno usiłującego odnaleźć równowagę i spokój po śmierci porwanego przezeń dla okupu dziecka.

Kolejny film Reygadasa, Ciche światło (2007), rozpoczyna się długim, statycznym ujęciem rozgwieżdżonego nieba. Tym samym obrazem film się kończy, spięty nim niczym klamrą. Rafał Syska podkreśla w swojej analizie filmu:

Reygadas nadaje melodramatycznej historii wymiar alegorycznej przypowieści, uruchamiając dla niej zgoła kosmiczną perspektywę; po realizacji zdjęć reżyser wspominał: „Zaczynamy i kończymy opowieść na gwiazdach. To jest początek i koniec historii. To jest uniwersum, poszerzenie i powiększenie rzeczy. Najpierw wkraczamy w życie trójki bohaterów, jakby to było centrum wszechświata, a potem zostawiamy ich losy i wracamy w kosmos"10.

Bohaterami filmu są żyjący w społeczności meksykańskiej menonici. Johan jest mężem Esther i statecznym ojcem kilkorga dzieci, który niespodzianie, także dla siebie samego, wikła się w romans z sąsiadką Marianne. Wobec swojej żony mężczyzna czuje przede wszystkim szacunek, przywiązanie i wdzięczność za opiekę nad nim oraz nad dziećmi. Ale to Marianne, nie żonę, kocha i pożąda. Opowieść jest realistyczna, uderza autentyzmem szczegółów, kostiumów, rekwizytów oraz podpatrzonych w codzienności zachowań menonitów, wyznaczanych przez surowe protestanckie reguły; zarazem jednak jest metafizyczna i przeniknięta nieuchwytną, ale intensywną duchowością. Pozornie wszystko dzieje się tak, jak w życiu mogłoby się wydarzyć, ale czuje się obecność „milczącego światła”, niedającą się zdefiniować, po ludzku niepojętą. Ta obecność - ewokowana m.in. przez rozświetlony słońcem pejzaż meksykańskiego interioru filmowany w długich, kontemplacyjnych ujęciach - przygotowuje widzów filmu na finałowy cud.

Otwierające film ujęcie nocnego nieba z lśniącymi punkcikami gwiazd, które powoli blednie w poświacie jutrzenki, sugeruje Bożą obecność - tytułowe „ciche światło”, które nieustannie towarzyszy poczynaniom bohaterów przede wszystkim pod postacią obrazów natury będącej częścią dzieła

10 R. Syska, Filmowy neomodernizm, Kraków 2014, s. 478. 
stworzenia. Długie, nakręcone techniką zdjęć poklatkowych ujęcie wschodu słońca zestawione jest ze zrealizowaną na podobnych zasadach finałową sekwencją zachodu słońca. Dwa momenty przełamywania się dnia i nocy zdają się przypominać, że oprócz pory ciemności i pory światła mamy na co dzień do czynienia z porami „pośrednimi” - świt i zmierzch nie znajdują się jednoznacznie ani po stronie światła, ani po stronie ciemności, są chwilami przenikania się dwóch porządków, zacierania granic - symbolizować mogą zatem sytuację, w jakiej znalazł się protagonista Johan. Jego późna miłość do Marianne zrodziła się niejako w porządku zmierzchu lub świtu i jest $\mathrm{z}$ pewnością silna, ale nie sposób stwierdzić, czy przynależy do sfery światła (dobra) czy ciemności (zła). Sam bohater zdaje się tego nie wiedzieć, do czego przyznaje się w rozmowie ze swoim ojcem, pastorem.

Otwierające i zamykające film ujęcia zdają się symbolizować coś jeszcze: obecną w dziele sferę konotacji biblijnych. Kiedy w pierwszej sekwencji Reygadas ukazuje rozgwieżdżone niebo, które stopniowo rozjaśnia się po wschodniej stronie, zdaje się nawiązywać do opisu stworzenia świata z Księgi Rodzaju, a zwłaszcza tego momentu, w którym Bóg oddziela światło od ciemności [Rdz 1, 3-5]. W kolejnej scenie reżyser portretuje rodzinę Johana przy stole, przed rozpoczęciem śniadania, w chwili porannej, cichej modlitwy. Pierwszym słowem, jakie pada z ekranu - a pada ich stosunkowo niewiele jak na trwający dwie i pół godziny film - jest „amen” - biblijne: „niech się tak stanie” - tak, jak tego chce Bóg.

Długie, kontemplacyjne ujęcia pozwalają widzowi dosłownie „wtopić się” w ekranowy świat przedstawiony. W scenie ustanawiającej (podobnie jak w całym filmie) nie ma muzyki - jedyne dźwięki to odgłosy natury, terkot maszyn, tykanie zegara, wskazujące na istotny upływ czasu. Czas, według menonitów, to jedyny element świata, nad którym człowiek nie ma władzy; chyba że kocha taką miłością, która „może góry przenosić”, jak to pokaże finał. Wszystko dzieje się bardzo powoli - cierpliwe oko kamery z uwagą przygląda się kąpieli dzieci, wspólnym posiłkom, pracy, po prostu zwykłemu życiu, które zyskuje jednak wymiar metafizyczny. Jest czymś więcej niż tylko dzianiem się tu i teraz; jest Bożym porządkiem.

Tradycyjnie uznaje się, że w kinie dźwiękowym nastrój poszczególnych ujęć współtworzy niediegetyczna muzyka. Reygadas rezygnuje z niej całkowicie, jej rolę przejmuje zmieniające się światło, które w subtelny sposób kreuje i zarazem unicestwia znaczenia. To co najbardziej istotne rozgrywa 
się w ciszy, subtelnie podbudowanej szumem traw albo śpiewem ptaków. Filmowy krajobraz przywołuje, a równocześnie ewokuje tytułowe „ciche światło”; na przestrzeni jednego ujęcia widzimy różnorodne jego natężenie, jakby sam pejzaż, skąpany w słońcu lub pod chmurami, dzienny albo nocny, przypominał nam o nieustannym zmaganiu się sił światłości i ciemności.

Kolejny film Carlosa Reygadasa, Post tenebras lux (2012), również rozpoczyna się sceną prezentującą pejzaż przepełniony wewnętrznym znaczeniem. Fabuła filmu składa się z luźno powiązanych ze sobą scen halucynacji, wspomnień, snów, marzeń bohaterów. Obraz filmowy urzeka swoją plastycznością, zapraszając widzów raczej do kontemplacji niż do pełnego zrozumienia opowiedzianej historii, a filmowe pejzaże pełnią rolę emocjonalnych dopowiedzeń o namiętnościach rozgrywających się w duszach bohaterów. Z sytuacją tego typu mamy do czynienia chociażby w scenie samobójczej śmierci Siete, zestawionej montażowo z obrazem upadających w puszczy wysokich, zielonych drzew, które na oczach widzów jedno po drugim zwalają się z upiornym skrzypieniem na ziemię.

Podobny zabieg odnajdziemy w filmowej scenie ustanawiającej. Wprowadza ona odbiorców w atmosferę filmu, coraz bardziej napiętą, gęstniejącą od nieuchwytnej grozy. Na wiejskim boisku po zroszonej deszczem trawie biegają krowy i psy, a wraz z nimi kilkuletnia dziewczynka. Dziecko jest zachwycone, skacze po kałużach i nawołuje zwierzęta. Powoli jednak, niemalże niezauważalnie, pejzaż staje się coraz ciemniejszy. Nadciąga burza, w półmroku krowy wydają się wielkie i niespokojne, a psy wyglądają jak demoniczne, złowrogie stwory. Dziewczynka woła mamę, ale ona nie nadchodzi. Niebo ciemnieje, od czasu do czasu rozświetlają je błyskawice; na tle ukazującego się wtedy krajobrazu pojawia się tytułowy napis: Post tenebras lux. Tytuł filmu przywołuje łacińską sentencję: „Po ciemnościach światło", nawiązującą do słów Hioba z Wulgaty: Post tenebras spero lucem „Po ciemnościach spodziewam się światła” [Job 17, 12].

Scena otwierająca film eksponuje strach dziecka i zarazem strach reżysera filmu o jego własne dzieci, które zresztą wcieliły się w filmowe role swoich rówieśników. W dziele Reygadasa odnajdziemy bowiem wątki autobiograficzne i zarazem zabiegi o charakterze autoterapeutycznym. Wewnętrzne pejzaże rozterek i emocji filmowych bohaterów są odzwierciedleniem niepokojów i lęków samego reżysera, a fabuła filmowa częściowo nawiązuje do 
autentycznych przeżyć rodziny Reygadasa, związanych z napadem złodziei na ich hacjendę podczas nieobecności właścicieli.

Protagonista filmu, Juan, głowa rodziny, pozornie ma wszystko, co jest potrzebne mężczyźnie do szczęścia: kochającą żonę, radosne dzieci, piękny dom na wsi, ogród, samochód, przyjaciół, psy. A jednak wciąż jest niezadowolony, sfrustrowany, egoistycznie zapatrzony w siebie i swoje niespełnione zachcianki. Dopiero na łożu śmierci dostrzega to, co w życiu najważniejsze: samo życie, jego bogactwo i piękno, dobroć dla innych, niewinność i czystość „świeżo wykąpanego niemowlęcia”. Juan mówi swojej żonie, że teraz już wie, że zawsze krzywdził tych, których kochał najbardziej i że pomimo pełni sił witalnych, miał chorą duszę. Podobnej chwili refleksji nad zmarnowanym życiem doświadczy chwilę później jego zabójca, zatrudniany przez bohatera do różnych prac domowych i darzony zaufaniem patrona, Siete.

W filmie Post tenebras lux - podobnie jak w Cichym świetle - nie pojawia się muzyka niediegetyczna. Jedynym utworem muzycznym jest piosenka śpiewana przez żonę Juana, Natalię, przy wtórze wykonywanego przez nią akompaniamentu na pianinie. Pełni ona kluczową rolę komentarza w scenie ukazującej Juana leżącego na łożu śmierci. Pozostałych sekwencji i scen nie ilustruje muzyka, a funkcję budowania nastroju przejmuje specyficznie kadrowany i filmowany pejzaż. Reygadas zastosował w swoim dziele klasyczny format obrazu 4:3, który wyświetlany we współczesnych kinach panoramicznych budzi skojarzenia z ekranem telewizora. Na kamerę nałożone zostały specjalne filtry i soczewki, dzięki którym obraz jest ostry w środku i rozmyty po brzegach. Dzięki tym zabiegom pejzaż filmowy jest rozmazany przy krawędziach ekranu, nakłada się na siebie i jest podwojony, a nawet zwielokrotniony, jakby konstytuowany był i przywoływany przez subiektywne wspomnienia poszczególnych bohaterów. Tego typu optyka pojawia się w pierwszej scenie filmowej (będącej zapewne sekwencją snu małej Ruth), a także w scenach ukazujących dzieci Juana i Natalii bawiące się na podwórzu przy skale czy spędzające wolny czas na plaży nad oceanem; rozmyty pejzaż w tle sugeruje, że mamy do czynienia ze wspomnieniami Natalii, przywoływanymi przez nią już po śmierci jej męża.

W ostatnim jak na razie filmie Reygadasa, Nasz czas (2018), opowieść o meandrach zdrady małżeńskiej i perypetiach miłosnego trójkąta przeplatana jest również obrazami meksykańskiego interioru, pięknego, a zarazem surowego. Zmagania bohaterów zestawione zostały z bataliami byków 
uganiających się po pastwiskach na rancho, a także z galopadami jeźdźców na koniach. W ten sposób opowieść o namiętnościach bohaterów przyrównana zostaje do zwierzęcych instynktów żywiołowego pędu, agresji i pożądania. Szczególnie sugestywna i urzekająca swoim „dzikim” pięknem jest filmowana w długich ujęciach scena finałowa, ukazująca potyczki byków na pastwisku okrytym poranną mgłą. Tym razem scenie towarzyszy muzyka budująca nastrój; Reygadas wykorzystał tu utwór Islands, zamykający album zespołu King Crimson o tymże tytule.

Bohaterami filmu są małżonkowie, którzy decydują się na eksperyment swobodnego, otwartego związku dopuszczającego miłosne fascynacje pozamałżeńskie, a nawet zdradę w imię opacznie rozumianej wolności. Ale erotyczna swoboda, na którą godzą się pewni stałości swojego długoletniego związku mąż i żona, okazuje się fikcją, grą pozorów, wciągającą ich w matnię zagubienia i rozchwiania emocjonalnego. Pozornie wyzwolony z obyczajowych konwenansów protagonista zmienia się w zazdrosnego sutenera, a jego żona, nawiązująca z „tym trzecim” romans, zostaje sprowadzona do bezwolnego przedmiotu męskiej umowy i gry pomiędzy mężem a kochankiem.

Wydarzenia rozgrywające się na rancho mają w tle piękny, dziki i surowy pejzaż meksykańskiego interioru. Protagonista filmowy hoduje byki do walki na arenie. Reżyser zestawia ze sobą obrazy zmagających się wewnętrznie oraz pomiędzy sobą ludzi z ujęciami walczących ze sobą byków. W jednej ze scen, okrutnej w brutalnym realizmie długich ujęć, widzimy, jak byk rozpruwa brzuch mułowi, który jest zaprzężony do wózka i nie może uciec. Reygadas pokazuje w swoim filmie, jak człowiek stwarza ujście dla dzikich instynktów pożądania i agresji, tworząc dzieła sztuki: poezję, malarstwo czy muzykę. Ale zarazem śledzi okiem kamery nieokiełznane, potężne zwierzęta, bezpośrednio dające ujście swoim erotycznym namiętnościom w opozycji do ludzi, którzy bezskutecznie usiłują obudzić w sobie podobne, niczym nieskrępowane zachowania. Natura od dawna nie jest już domem ludzi, jest nim kultura, a ona ogranicza człowieka, stawia tamy jego instynktom, zarazem chwyta go w pułapkę zdradliwych pozorów i konwenansów.

Pejzaż w filmie Nasz czas nie jest tylko tłem dla opowiadanej historii rozgrywającej się na wiejskim rancho. Podobnie jak w poprzednich filmach Reygadasa, odzwierciedla on stany emocjonalne oraz duchowe, a zarazem perypetie życiowe protagonistów. I tak namiętności buzujące w duszy bohaterki oddaje obraz samochodu pędzącego w deszczu przez meksykański 
interior, zaś emocje zazdrości przeżywane przez jej męża wyraża scena galopu jeźdźców na koniach przez dziki, porośnięty krzakami i wysokimi trawami krajobraz.

We wszystkich filmach Reygadasa pojawia się istotna sfera transcendencji (wyrażana poprzez odniesienia do Boga lub do natury), której przejawy można dostrzec w filmowej przestrzeni, w pejzażach nacechowanych symbolicznym przekazem. Odnaleźć ją możemy w zastosowanych przez reżysera środkach wyrazowych, które składają się na to, co Paul Schrader nazywa „stylem transcendencji”"1. Ideą tego stylu jest kontemplacyjna forma filmu, a jego naczelną właściwością specyficzna warstwa temporalna i przestrzenna jako bezpośrednio przywołująca sferę sacrum. Czas oraz przestrzeń filmowa stylu transcendentalnego wyrażają się w: długich ujęciach, rezygnacji z montażu eliptycznego, preferowaniu montażu wewnątrzkadrowego oraz minimalizacji narracji na rzecz estetyzacji obrazu.

W przypadku reżysera meksykańskiego styl transcendentalny wyraża się najpełniej w ukazywaniu rzeczywistości w taki sposób, aby ze zwykłego przedstawienia świata wyłonił się obraz cudowny, aby z profanum emanowało sacrum. Środkami artystycznymi służącymi temu celowi są przedłużające się ujęcia filmowe prezentujące pejzaże emanujące wewnętrznym, symbolicznym znaczeniem. Tego typu przedstawienia znajdziemy w obrazach górskich szczytów w Japón i Bitwie w niebie, a także w scenie ustanawiającej i kończącej Ciche światło, w prologu Post tenebras lux oraz w epilogu Naszego czasu; są one filmowane w długich, statycznych ujęciach, przywołujących patos, majestat i piękno.

Misterium życia i śmierci, konstytuujące fabularne wątki filmów Reygadasa, nie jest jednak tożsame z prostym przesłaniem o charakterze etycznym czy moralizatorskim. Dzieła meksykańskiego reżysera, chociaż krytykujące brak głębi, pustkę i alienację kultury współczesnej, nie proponują konkretnych dróg wyjścia z impasu, w który wpada dzisiejszy nienasycony konsument i zarazem kreator własnej podmiotowości. Ukazują bohaterów w rozdarciu pomiędzy tym, co cielesne, zmysłowe, pożądane jako zaspokojenie natychmiastowej podniety, a tym, co duchowe, niezaspokojone, domagające się transcendencji i niemożliwe do osiągnięcia. Bohater filmów

${ }^{11}$ P. Schrader, Transcendental Style in Film: Ozu, Bresson, Dreyer, Berkeley-Los Angeles-London 1972, s. 21-36. 
Reygadasa to człowiek pragnący wznieść się ponad marazm niespełnionego życia, a zarazem ktoś, kto utracił możliwość duchowego odrodzenia. Nie jest mu dane pocieszenie wypływające $\mathrm{z}$ wiary, bo ją zagubił; religijne gesty, nawet jeśli je wykonuje, stają się dla niego martwym rytuałem, który nie ma już mocy uzdrowienia - rytuałem niemającym możliwości oddziaływania na zachowania i postawy, a jedynie wzmagającym wyobcowanie i frustrację. Równie niemożliwy jest dla niego powrót do żywiołowej, nieskrępowanej niczym natury, gdyż żyje uwikłany w kulturowe formy (bycia Meksykaninem, białym lub Metysem, mężczyzną - latynoskim macho lub kobietą - samotną i wyemancypowaną bądź osadzoną w rodzinie etc.), które stały się jego domem, a zarazem pułapką-więzieniem. Dlatego nie potrafi zrozumieć ani wyrazić siebie, a czynione przez niego rozpaczliwe poszukiwania sensu istnienia okazują się nie tylko nietrafione, ale często wręcz zgubne dla niego samego i jego najbliższych.

Tego typu postawa, charakterystyczna dla bohaterów Reygadasowskich opowieści, odzwierciedla równocześnie światopogląd samego reżysera. Ukazywane na ekranie pejzaże opowiadają (pośrednio) o pustce i wyobcowaniu protagonistów, o przeżywanych przez nich kryzysach i zagubieniu, o głodzie sacrum i potrzebie transcendencji, a zarazem niemożności jej osiągnięcia, równocześnie ujawniają przemyślenia i przeżycia ich kreatora, zgodnie z zasadą, którą Juan Eduardo Cirlot określa jako paralelę pomiędzy tym, co widzialne a tym, co odczuwane:

Już doktryna tradycyjna wyjaśniała, że rozmaite światy (lub miejsca) to w rzeczywistości jedynie różne stany. Stąd „wybrane miejsca” mają być poniekąd obrazem-okazją, która w nich się realizuje. „Miejsce schadzki”, jeśli jest autentyczne, nie zaś arbitralne ani przypadkowe, stanowi transpozycję w przestrzeń i topografię tego, co w nim się spotyka lub urzeczywistnia. Jakkolwiek rewolucyjnie brzmiałyby tego rodzaju stwierdzenia, potwierdzają je „psychologia kształtu” (Gestalt) i izomorfizm, dla których różnica między formalnymi procesami psychicznymi i fizycznymi jest jedynie zewnętrzna ${ }^{12}$.

Zgodnie z tym tropem interpretacyjnym wewnętrzne pejzaże Carlosa Reygadasa i nacechowane symbolicznym znaczeniem pejzaże wykreowane

12 J.E. Cirlot, op. cit., s. 305. 
przez niego w filmach (również uwewnętrzniające się w psychice filmowych bohaterów) splatają się w jedno, tworząc autorską kreację. Realizuje ona ujawnienie się „ja” sylleptycznego - w rozumieniu terminu przez Ryszarda Nycza:

"Ja" sylleptyczne - mówiąc najprościej - to „ja”, które musi być rozumiane na dwa odmienne sposoby równocześnie: a mianowicie jako prawdziwe i jako zmyślone, jako empiryczne i jako tekstowe, jako autentyczne i jako fikcyjno-powieściowe ${ }^{13}$.

Bohaterowie filmów Carlosa Reygadasa odzwierciedlają jego osobiste marzenia i lęki, reprezentują jego światopogląd. Rozterki reżysera, będące równocześnie rozterkami jego protagonistów, wyrażone językiem filmowych obrazów, zostają obnażone przed widzami, ukazane w ekranowych wydarzeniach i osadzone w pejzażach im towarzyszących. Dzięki temu wyobraźnię artystyczną Carlosa Reygadasa można odczytywać za pośrednictwem tworzonych przez niego ekranowych (kraj)obrazów. Można także podjąć trud interpretacji jego światopoglądu oraz autorskiej wizji człowieka i świata na podstawie zrealizowanych przez niego filmowych opowieści.

\section{Bibliografia}

Matilde Battistini, Symbole i alegorie, tłum. K. Dyjas-Fezzi, Arkady, Warszawa 2005. Jean Eduardo Cirlot, Słownik symboli, tłum. I. Kania, Znak, Kraków 2006.

Katarzyna Citko, Sacrum i profanum w kinie Carlosa Reygadasa, [w:] Blask religii. Media w poszukiwaniu sacrum i autorytetów, red. M. Sokołowski, Wydawnictwo Adam Marszałek, Toruń 2016.

Katarzyna Citko, Wątki autobiograficzne w "Post tenebras lux” Carlosa Reygadasa,

[w:] Kino, film, psychologia, red. A. Ogonowska, Wydawnictwo Edukacyjne, Kraków 2017.

Ryszard Nycz, Język modernizmu. Prolegomena historyczno-literackie, Wydawnictwo Naukowe UMK, Toruń 2013.

Pismo Święte Starego i Nowego Testamentu. Biblia Tysiąclecia, wyd. V, Pallotinum, Poznań 2013.

Paul Schrader, Transcendental Style in Film: Ozu, Bresson, Dreyer, University of California Press, Berkeley-Los Angeles-London, 1972.

13 R. Nycz, Język modernizmu. Prolegomena historyczno-literackie, Toruń 2013, s. 108. 
Małgorzata Steciak, Kino współczesne. Carlos Reygadas: Film jest naczyniem, „Ekrany” 2019, nr 3-4(49-50).

Rafał Syska, Filmowy neomodernizm, Avalon, Kraków 2014.

\section{Źródła internetowe}

Carlos Reygadas, http://www.imdb.com/name/nm1196161/ [dostęp 23.09.2018].

Scott Foundas, Redemption, Religion, and Reconsideration, with Director Carlos

Reygadas, https://www.villagevoice.com/2009/01/07/redemption-religion-an-

d-reconsideration-with-director-carlos-reygadas [dostęp 21.09.2016].

Krzysztof Kornacki, Kino niezagadujace tajemnicy, http://wiez.com.pl/2019/08/27/

kino-niezagadujace-tajemnicy [dostęp 12.07.2018].

Raúl Miranda López, El estilo audiovisual de Carlos Reygadas, http://www.correcamara.com.mx/inicio/int.php?mod=historia_detalle\&id_historia=812 [dostęp 3.04.2016].

Javier Marimón Miyares, El cine poético en Carlos Reygadas, https://core.ac.uk/download/pdf/79654461.pdf [dostęp 17.03.2019].

\section{The Symbolism of the (Internal) Landscape in the Films by Carlos Reygadas}

The article describes the representations of landscapes in the films by Carlos Reygadas, whose role is to evoke the transcendental film style (as understood by Paul Schrader), and to express the experiences, thoughts and action of the screen protagonists. Landscapes perform various functions in Reygadas's films. They are not only a background for film events or emphasize the mood and aura of contemplation of film images, but also a symbolic representation of emotions and experiences of the film's heroes, and evoke the sphere of transcendence and sacrum, important for spiritual dilemmas and searches of protagonists. The article cites and discusses all of Reygadas's fictional films made so far, which gives us the opportunity to compare them and demonstrate their mutual inspiration, and to continue the proprietary workshop, stylistic and thematic solutions. The research method in the article is analytical description of selected landscapes that play an important role in Carlos Reygadas' films and the interpretation of the symbols contained in them, in accordance with the phenomenological and hermeneutic perspective. Interpretative phenomenological analysis enables, as the research tool used in the article, both the description of images (landscapes) appearing in Reygadas' films and the presentation of their symbolic meanings. The subject of interest in interpretative phenomenological analysis is the life situation of film heroes, entangled in a chaos of various events and forced to make various choices. In accordance with the attitude adopted by the director, which can be described 
as the syllaptic 'I' (a term used in the meaning given to him by Ryszard Nycz), they are also an exemplification of the worldview and the essence of the artistic creation by the author: Carlos Reygadas himself.

Keywords: film, Carlos Reygadas, landscape, symbolism, transcendental style, syllaptic 'I'

Data otrzymania tekstu: $30.11 .2020 \mathrm{r}$.

Data zakończenia procesu recenzyjnego: 9.02.2021 r.

Data akceptacji tekstu do druku: 15.02.2021 r. 